\title{
KAJIAN PERBEDAAN PEMAHAMAN TENTANG PERTANGGUNGJAWABAN PELAKSANAAN KEGIATAN UNTUK BELANJA MAKAN MINUM \\ (Studi Kasus pada Badan Kepegawaian Daerah Provinsi Sulawesi Utara Tahun 2013)
}

\author{
Supriyadi Subu \\ Lidya Mawingkere \\ Lintje Kalangi
}

(email: supriyadisubu86@gmail.com)

\begin{abstract}
This study aims to determine the problems in the accountability of the activities at BKD North Sulawesi, as well as to gain a shared understanding between the auditor of the Inspectorate with BKD North Sulawesi regarding accountability of eating and drinking expenditure in the designation in accordance with programs and activities that are organized in the DPA SKPD, so that there are no more errors in the document creation process of accountability by implementing activities.

The object of this research is the Regional Employment Board of North Sulawesi Province and the Inspectorate of North Sulawesi province in which researchers took multiple samples among others, Treasurer Expenditure on BKD North Sulawesi province and DKP North Sulawesi Province, Head of Sub Division of Planning and Finance at BKD and DKP North Sulawesi Province, Staff At BKD, Flammable related to the functions of Treasury and Verification, Auditor and Functional Implementation Supervisory Affairs Regional Government (P2UPD) in North Sulawesi Provincial Inspectorate. Sample numbering 12 people. Data collected in the form of primary data obtained through interviews with a sample. Tesis ini using qualitative research approaches.

The results showed that there are some things that a problem is found in the differences in the understanding of the accountability of the budget for eating and drinking expenditure at BKD North Sulawesi province with the auditors of the Inspectorate of North Sulawesi province. The other thing that is encountered is the problem of communication, and understanding of the regulations are still lacking.
\end{abstract}

Keywords: Understanding Differences, Accountability of Activities Implementation, Eat and Drink Expenditure.

\section{PENDAHULUAN}

Pemeriksaan yang dilakukan oleh Inspektorat pada umumnya dilaksanakan tiga kali dalam setahun yaitu pemeriksaan Reguler I yang biasanya dilaksanakan pada Bulan Mei atau Juni dimana fokusnya adalah pertanggungjawaban kegiatan APBD pada semester pertama, pemeriksaan Reguler II biasanya dilaksanakan pada bulan November atau Desember fokusnya adalah pertanggungjawaban kegiatan yang tertata dalam APBD untuk semester II, kemudian Review atas Laporan Keuangan Pemerintah Daerah dalam hal ini yang menjadi objek pemeriksaan adalah Laporan Keuangan Tahunan yang dibuat oleh masing-masing Satuan Kerja Perangkat Daerah (SKPD) di Lingkungan Pemerintah Provinsi Sulawesi Utara yang telah di rekonsiliasi oleh Bidang Akuntansi Badan Pengelola Keuangan dan Barang Milik Daerah Provinsi Sulawesi Utara.

Proses pengelolaan dan pertanggungjawaban pelaksanaan kegiatan yang terdapat dalam Dokumen Pelaksanaan Anggaran terdiri dari dua bagian penting yang tidak terpisahkan dalam pelaksanaan DPASKPD yaitu proses penelitian kelengkapan berkas/dokumen pertanggungjawaban biasanya disebut Surat Keterangan Pertanggungjawaban (SPJ) oleh bendahara pengeluaran masing-masing SKPD di Bidang Perbendaharaan Badan Pengelola Keuangan dan Barang Milik Daerah Provinsi Sulawesi Utara selaku, dalam proses ini para petugas di loket Bidang Perbendaharaan BPK-BMD biasanya akan meneliti kelengkapan dan keabsahan dokumen pertanggungjawaban pelaksanaan kegiatan DPA SKPD untuk tujuan Ganti Uang Persediaan (GU), permohonan Tambahan Uang Persediaan (TU) atau dokumen untuk pencairan pelaksanaan kegiatan yang bersifat Langsung (LS). Para pelaksana kegiatan di SKPD dalam hal 
ini adalah Pejabat Pelaksana Teknis Kegiatan (PPTK) melalui bendahara pengeluaran masing-masing SKPD menyampaikan dokumen pertanggungjawaban pelaksanaan kegiatan dalam DPA SKPD ke bidang perbendaharaan BPK-BMD, jika dokumen pertanggungjawaban tersebut dinyatakan telah lengkap sesuai dengan yang disyaratkan maka Bidang Perbendaharaan BPK-BMD akan mengeluarkan Surat Perintah Pencairan Dana (SP2D) yang ditandatangani oleh Kepala Bidang Perbendaharaan BPK-BMD atas nama Kepala BPK-BMD, yang menjadi dasar pencairan dana/anggaran untuk pelaksanaan kegiatan yang terdapat dalam DPA SKPD telah mendapat persetujuan dari Kepala BPK-BMD selaku Bendahara Umum Daerah (BUD), namun apabila dokumen pertanggungjawaban tersebut dianggap tidak lengkap, tidak sah atau tidak memenuhi persyaratan pertanggungjawabkan yang telah ditetapkan - melalui Peraturan Gubernur Sulawesi Utara tentang Mekanisme Pertangungjawaban Pelaksanaan APBD atau Peraturan Gubernur Sulawesi Utara tentang Kebijakan Akuntansi yang berlaku di Lingkungan Pemerintah Provinsi Sulawesi Utara yang diterbitkan setiap tahun sebagai pedoman pelaksanaan anggaran di Lingkungan Pemerintah Provinsi Sulawesi Utara - maka dokumen tersebut dikembalikan kepada SKPD yang bersangkutan untuk diperbaiki atau dilengkapi. Melihat betapa pentingnya fungsi pada Bidang Perbendaharaan BPK-BMD ini, maka seharusnya standar yang digunakan adalah baku, jelas, sesuai dengan aturan yang berlaku supaya SKPD yang nanti akan mempertanggungjawabkan pelaksanaan kegiatan yang tertata didalam DPA, memperoleh kepastian.

Dalam beberapa kasus pemeriksaan laporan pertanggungjawaban pelaksanaan kegiatan/anggaran ditemui bahwa perbedaan pemahaman antara auditor dan auditee adalah permasalahan yang menjadi temuan, padahal keduanya bisa jadi berpegang pada aturan yang sama dalam pelaksanaannya. Perbedaan pemahaman yang timbul bisa jadi diakibatkan oleh beberapa hal antara lain Perbedaan Pemahaman tentang aturan yang dipakai, kurangnya pemahaman mengenai aturan yang dipakai, perbedaan versi aturan yang dipakai atau bisa juga dikarenakan permasalahan yang lain.

Latar belakang di atas membuat peneliti tertarik untuk melakukan penelitian dengan judul

"Kajian Perbedaan Pemahaman tentang Pertanggungjawaban Pelaksanaan Kegiatan Untuk Belanja Makan Minum (Studi Kasus pada Badan Kepegawaian Daerah Provinsi Sulawesi Utara Tahun 2013)".

\section{TINJAUAN PUSTAKA}

\subsection{Teori Persepsi}

Persepsi adalah sebuah kata yang sering kita dengar, terkadang kita mengartikan persepsi sebagai pandangan dari sudut pandang kita dalam menyikapi suatu fenomena secara umum definisi persepsi adalah proses internal yang memungkinkan kita memilih, mengorganisasikan, dan menafsirkan rangsang dari luar lingkungan, dan proses tersebut mempengaruhi perilaku seseorang (Mulyana, 2004:19). Persepsi adalah proses mental yang terjadi pada diri manusia yang akan menunjukkan bagaimana seseorang melihat, mendengar, merasakan, memberi, serta meraba (kerja indra) disekitar kita (Widayatun, 1999:12). Persepsi juga diartikan sebagai daya mengenal sesuatu yang hadir dalam sifatnya yang kongkrit jasmaniah, bukan yang sifatnya batiniah, seperti benda, barang, kualitas, atau perbedaan antara dua hal atau lebih yang diperoleh melalui proses mengamati, mengetahui, dan mengartikan setelah panca inderanya mendapat rangsang (Baihaqi, dkk, 2005:7).

\subsection{Hubungan antara Persepsi dan Komunikasi}

Setelah mempelajari hal-hal dalam persepsi, lalu bagaimanakah hubungan antara persepsi dan komunikasi. Dapat dijelaskan bahwa makna merupakan jantungnya komunikasi dan persepsi itu mempertajam komunikasi. Persepsi merupakan inti dari komunikasi sebab jika persepsi tidak akurat, maka komunikasi tidak akan berjalan secara efektif. Selain itu,akan menentukan kita memilih pesan dan mengabaikan pesan lain dan pastinya setiap orang memiliki persepsi yang berbeda.

\subsection{Pemeriksaan Oleh Inspektorat}

Pengawasan erat sekali kaitannya dengan perencanaan, yang artinya harus ada sesuatu obyek yang diawasi, jadi pengawasan hanya akan berjalan kalau ada rencana program/kegiatan untuk diawasi. Rencana digunakan sebagai standar untuk mengawasi, sehingga tanpa rencana hanya sekedar meraba- 
raba. Apabila rencana telah ditetapkan dengan tepat dan memulai pengawasannya begitu rencana dilaksanakan, maka tidak ada hal yang menyimpang. Maksud pengawasan itu dalam rumusan yang sederhana adalah untuk memahami dan menemukan apa yang salah demi perbaikan di masa mendatang. Hal itu sebetulnya sudah disadari oleh semua pihak baik yang mengawasi maupun pihak yang diawasi termasuk masyarakat awam. Sedangkan tujuan pengawasan itu adalah untuk meningkatkan pendayagunaan aparatur negara dalam melaksanakan tugas-tugas umum pemerintahan dan pembangunan menuju terwujudnya pemerintahan yang baik dan bersih (good and clean government).

Umumnya pengawasan terdiri dari 3 (tiga) langkah yaitu:

1. Menentukan standar

Standar pengukuran yang dipakai biasanya sudah ditentukan oleh penanggung jawab program/kegiatan, yang selanjutnya pengawas mengukur hasil-hasilnya dengan mengacu kepada standar tersebut. Hasil pengukurannya sebagai dasar untuk apakah pelaksanaan kegiatan telah diselenggarakan secara efisien, efektif, ekonomis dan tertib aturan. Pengawasan akan sia-sia tanpa tindakan perbaikan, apabila dalam pengukuran hasil ditemukan keadaan tidak sesuai standar yang direncanakan, maka pengawas harus menganjurkan tindakan perbaikan. Mengetahui adanya ketidakberesan, maka pengawas berkewajiban melaporkannya kepada pihak yang berwenang.

2. Mengukur hasil atas dasar standard

Hasil Pengawasan dan Pemeriksaan kemudian dibandingkan dengan standar yang telah ditetapkan dalam hal ini biasanya standar yang dipakai adalah Undang-undang, Peraturan Pemerintah atau regulasi sejenis yang mengatur teknis penyelenggaraan kegiatan dalam pengawasan serta memiliki dasar hukum yang kuat dan jelas.

3. Mengambil tindakan perbaikan yang diperlukan.

Dalam proses pemeriksaan sekiranya ditemukan hal-hal yang tidak sesuai dengan standar yang digunakan untuk pemeriksaan terutama dalam hal pengelolaan dan pertanggungjawaban keuangan daerah, maka auditor selaku pemeriksa akan memberikan rekomendasi mengenai temuan tersebut supaya tidak ditemukan lagi hal serupa dalam pemeriksaan mendatang/Tahun anggaran selanjutnya.

Oleh karena itu dengan pelaksanaan pembentukan kualitas aparatur pemerintahan, maka ditunjuklah inspektorat selaku badan pengasawan internal pemerintah pada provinsi dan kabupaten/kota, yang berfungsi untuk mengawasi kinerja pemerintah, pada kegiatan pembangunan, kegiatan kepegawaian, dan pelayanan pada masyarakat. Agar tercipta pemerintahan yang baik (Good Governance) dan bersih di daerah.

\subsection{Penelitian Terdahulu}

Mengingat bahwa penelitian ini adalah penelitian yang diusulkan oleh peneliti didasarkan pada pengalaman peneliti maka peneliti belum menemukan penelitian terdahulu yang sama dengan judul, objek bahkan pendekatan penelitian dengan metode kualitatif yang digunakan, maka peneliti mencoba memilih beberapa penelitian-penelitian terdahulu yang menjadi pembanding dengan penelitian ini antara lain :

1. Penelitan yang dilakukan oleh Indrastanti dan Wahyono pada Tahun 2001 dengan judul penelitian : "Persepsi Auditor Publik dan Auditor Intern Terhadap Struktur Pengedalian Intern, dengan tujuan penelitian untuk mengetahui perbedaan persepsi antara auditor public dan auditor internal terhadap struktur pengendalian intern, persamaan dengan penelitian ini adalah sama-sama mengangkat tentang masalah perbedaan persepsi, sementara perbedaan terletak pada objek dimana peneliti terdahulu melakukan penelitian dengan membandingkan perbedaan persepsi auditor internal dengan auditor publik, sedangkan peneliti mengangkat perbedaan persepsi antara auditor dengan pelaksana anggaran.

2. Penelitian yang dilakukan oleh Diah Ananta Setyorini pada tahun 2010 dengan judul "Analisis Audit Expectation Gap pada Pemerintah Daerah (Studi Empiris di Kabupaten Sragen) dengan tujuan penelitian untuk mendapatkan bukti secara empiris mengenai audit expectation gap diantara auditor pemerintah (BPK) dan pengguna laporan keuangan pemerintah daerah mengenai peran auditor, independensi auditor dan pengetahuan audit. Persamaan dari penelitian ini adalah sama-sama mengangkat tema permasalahan tentang perbedaan pandangan, keyakinan dan persepsi. Sementara perbedaannya terletak pada objeknya dimana peneliti terdahulu membandingkan perbedaan harapan 
atau keyakinan pengguna laporan keuangan pemerintah daerah, sedangkan peneliti mengangkat perbedaan persepsi auditor dengan pelaksana anggaran.

3. Penelitian yang dilakukan oleh Verly Siswanto dan Armanto Witjaksono, SE, Ak. Pada Tahun 2012 dengan judul "Persepsi Auditor di Kantor Akuntan Publik berkenaan dengan Fraud". Tujuan penelitian ini adalah untuk mengetahui bagaimana persepsi auditor (dalam penelitian ini penulis meneliti dari sisi pengalaman kerja) yang bekerja di Kantor Akuntan Publik berkenaan dengan Fraud. Presepsi tersebut ditinjau dari Fraud Triangle sebagai factor pemicu terjadinya kecurangan dalam pendeteksian kecurangan. Persamaannya adalah sama-sama mengangkat masalah tentang perbedaan persepsi, dan perbedaannya adalah pada objek penelitian dimana peneliti terdahulu membandingkan persepsi auditor yang berpengalaman dengan auditor yang belum berpengalaman, sementara peneliti menagnkat perbedaan pemahaman auditor denagn pelaksana anggaran/auditee. Peneliti terdahulu menggunakan pendekatan penelitian kuantitatif dengan pengolahan data statistic sementara peneliti menggunakan pendekatan penelitian kualitatif deskriptif.

\section{KERANGKA KOSEPTUAL}

Pelaksanaan anggaran merupakan salah satu tahapan dari siklus anggaran yang dimulaidari perencanaan anggaran, penetapan dan pengesahan anggaran oleh Dewan Perwakilan Rakyat (DPR), pelaksanaan anggaran, pengawasan anggaran dan pertanggungjawaban pelaksanaan anggaran.

Siklus Anggaran

1. Tahapan Persiapan dan Penyusunan Anggaran

Tahapan persiapan dan penyusunan anggaran melibatkan kemampuan analisis perkembangan anggaran atau taksiran atas dasar hasil atau output dan outcome yang disesuaikan dengan tujuan organisasi. Hal ini tertuang dalam Recana Anggaran Biaya (RAB), Term Of Reverence (TOR) dan Rencana Kerja Anggaran Satuan Kerja Pemerintah Daerah (RKA - SKPD).

2. Tahap Ratifikasi

Tahap ratisfikasi anggaran merupakan tahapan yang rumit bagi lembaga eksekutif, karena sarat dengan muatan politis yang melingkupi hubungan antara lembaga eksekutif dengan lembaga legislatif. Hal tersebut didasarkan pada dua hal yaitu: pemisahan peran antar kedua lembaga tersebut, yaitu lembaga eksekutif sebagai pihak yang mengajukan anggaran dibagi menjadi satker (satuan kerja) sedangkan pihak legislatif sebagai pihak yang menentukan (menerima atau menolak) anggaran yang diajukan akan menimbulkan kepentingan politik yang berimbas pada lemahnya pengkritisan rasional terhadap anggaran (Asmadewa, 2006).

3. Tahap Implementasi

Implementasi anggaran sangat dipengaruhi oleh sisim dan prosedur yang memadai. Pemanfaatan posisi bagian keuangan yang sangat pentig pada keluar masuknya dana yang sering disalahgunakan oknum harus segera dihapus dengan diciptakannya sistem pengendalian intern yang baik (Asmadewa, 2006).

4. Tahap pelaporan dan Evaluasi

Tahap pelaporan evaluasi anggaran terkait dengan prinsip akuntabilitas, yang mempunyai ciri berisikan umpan balik pengukuran kinerja anggaran, yang akan menjadi informasi masukan bagi perencanaan sikluas anggaran berikutnya.

\section{METODE PENELITIAN}

Penelitian ini menggunakan penelitian pendekatan kualitatif. (Poerwandari 2007) menyatakan bahwa penelitian kualitatif adalah penelitian yang menghasilkan dan mengolah data yang sifatnya deskriptif, seperti transkripsi wawancara, catatan lapangan, gambar, foto, rekaman video dan lain-lain.

Penelitian kualitatif perlu menekankan pada pentingnya kedekatan dengan orang-orang dan situasi penelitian, agar peneliti memperoleh pemahaman jelas tentang realitas dan kondisi kehidupan nyata (Poerwandari 2007). 
Subjek yang menjadi populasi penelitian ini adalah bendahara pengeluaran dan staf yang telah beberapa kali menjadi objek pemeriksaan atau dalam hal ini disebut auditee, auditor dan P2UPD yang ada di Inspektorat Provinsi Sulawesi Utara, beberapa pejabat terkait Fungsi Pengawasan dan Pengendalian Intern.

Instrumen penelitian yang dipakai dalam penelitian ini adalah wawancara (menggunakan bantuan alat rekaman dan alat tulis) yang dilakukan dengan bendahara pengeluaran yang telah beberapa kali menjadi objek pemeriksaan pada BKD Prov. Sulut dan DKPD Prov. Sulut, Kepala Sub Bagian Perencanaan Keuangan pada BKD Prov. Sulut dan DKP Prov. Sulut, Staf pada Sekretariat BKD Prov. Sulut, auditor dan fungsional P2UPD yang ada di Inspektorat Provinsi Sulawesi Utara, beberapa pejabat terkait Fungsi Pengawasan dan Pengendalian Intern.

Adapun lokasi penelitian yang dipilih oleh peneliti adalah Pemerintahan Daerah Provinsi Sulawesi Utara yang difokuskan pada Badan Kepegawaian Daerah Provinsi Sulawesi Utara. Peneliti melakukan penelitian dalam kurun waktu kurang lebih 1 Tahun dengan bantuan dan arahan dari dosen pembimbing.

Teknik analisa yang digunakan adalah teknik analisa data kualitatif. Dalam menganalisa penelitian kualitatif terdapat beberapa tahapan-tahapan yang perlu dilakukan (Marshall dan Rossman dalam Kabalmay, 2002), diantaranya :

1. Mengorganisasikan Data

2. Pengelompokan berdasarkan Kategori, Tema dan pola jawaban

3. Menguji Asumsi atau Permasalahan yang ada terhadap Data

4. Mencari Alternatif Penjelasan bagi Data

5. Menulis Hasil Penelitian

\section{Hasil Penelitian dan Pembahasan}

Sesungguhnya ada kaitan yang erat antara BPK-BMD dengan Inspektorat selaku pihak pengawas dan pemeriksa dokumen-dokumen terkait pertanggungjawaban pelaksanaan kegiatan yang tertata dalam DPA-SKPD yang tentu saja berkaitan dengan konsekuensi penggunaan anggaran/dana pemerintah yang harus dipertanggungjawabkan, karena biasanya dokumen yang telah diteliti kelengkapannya oleh Bidang Perbendaharaan yang telah dinyatakan sah, lengkap dan telah disetujui oleh BUD untuk mendapat pencairan dana itulah yang akan menjadi objek yang sama yang di berikan oleh pihak auditee (SKPD) pada saat Pemeriksaan oleh Inspektorat sebagai Surat Keterangan Pertanggungjawaban (SPJ) Pelaksanaan Kegiatan. Prakteknya, Dokumen SPJ yang telah diverifikasi di Bidang Perbendaharaan BPK-BMD dan telah mendapatkan Surat Perintah Pencairan Dana (SP2D) di satukan dokumen dan SP2D nya dan di filing sebagai arsip dokumen pertanggungjawaban biasanya wadah yang digunakan adalah Ordner yang nantinya diberi Label tergantung Dokumen Pertanggungjawaban digunakan untuk kegiatan-kegiatan yang pencairannya bersifat Ganti Uang Persediaan (GU), Tambahan Uang Persediaan (TU) atau Langsung (LS). Berdasarkan hasil Pemeriksaan Reguler I Inspektorat Daerah Provinsi Sulawesi Utara atas Pelaksanaan Tugas dan Fungsi, Pengelolaan Keuangan, Pengelolaan Kepegawaian Daerah dan Pengelolaan Barang Milik Daerah pada Badan Kepegawaian Daerah Provinsi Sulawesi Utara (tahun anggaran 2013) ditemukan bahwa terdapat belanja makanan dan minuman yang tidak dilengkapi dengan dokumen yang sah dan tidak lengkap sebagaimana yang disyaratkan oleh ketentuan Pasal 132 ayat (1) Peraturan Menteri Dalam Negeri Nomor 13 Tahun 2006 Tentang Pedoman Pengelolaan Keuangan Daerah sebagaimana diubah terakhir dengan Peraturan Menteri Dalam Negeri Nomor 21 Tahun 2011 Tentang Perubahan Kedua Atas Peraturan Menteri Dalam Negeri Nomor 13 Tahun 2006 Tentang Pedoman Pengelolaan Keuangan Daerah yang menyatakan bahwa :

"Setiap pengeluaran belanja atas beban APBD harus didukung dengan bukti yang lengkap dan sah."

Selanjutnya menurut pihak Auditor dari Inspektorat hal tersebut disebabkan karena bendahara pengeluaran dianggap kurang cermat dalam melakukan verifikasi atas pembayaran belanja makanan dan minuman pada kegiatan yang tertata dalam DPA Badan Kepegawaian Daerah Provinsi Sulawesi Utara Tahun Anggaran 2013. Hal ini tentu saja menjadi suatu teguran terhadap Kepala SKPD yang dianggap tidak mampu memantau dan menjalankan fungsi pengendalian intern terhadap pengeluaran anggaran atas belanja kegiatan. Padahal proses verifikasi sudah dijalankan dari tingkat staf (dalam hal ini dilakukan oleh 
Pembantu Pejabat Penatausahaan Keuangan Satuan Kerja Perangkat Daerah (PPK-SKPD) fungsi Verifikasi) dan Kemudian kembali di verifikasi oleh Bendahara Pengeluaran sebelum di bawa ke Bidang Perbendaharaan BPK-BMD untuk diteliti terakhir kali sebelum mendapatkan Surat Perintah Pencairan Dana (SP2D). Menjadi suatu pertanyaan kenapa dokumen pertanggungjawaban tersebut bisa lolos dari Pemeriksaan Keabsahan dan Kelengkapan Dokumen untuk pencairan dana pada Bidang Perbendaharaan BPK-BMD. Situasi ini memancing pertanyaan siapakah pihak yang seharusnya bertanggungjawab dan apakah tanggungjawab sepenuhnya ada di tangan SKPD selaku pelaksana kegiatan dan pengguna anggaran. Selanjutnya lebih jauh lagi, seandainya bukti yang diajukan dianggap tidak lengkap atau tidak sah lantas mengapa diloloskan dan disetujui untuk mendapatkan SP2D (Sumber data P2HP Inspektorat Provinsi Sulawesi atas Pemeriksaan Reguler I pada BKD Prov. Sulut).

Setelah diadakan rapat intern pada Badan Kepegawaian Daerah Provinsi Sulawesi Utara dengan agenda rapat untuk membahas Laporan Hasil Pemeriksaan (LHP) yang didalamnya memuat tentang temuan-temuan oleh Tim Audit dari Insepktorat Provinsi Sulawesi Utara yang dipimpin langsung oleh Kepala Badan Kepegawaian Daerah Provinsi Sulawesi Utara dan dihadiri oleh PPK SKPD yang dijabat oleh Sektretaris BKD Provinsi Sulawesi Utara serta semua PPTK yang dijabat oleh Kepala-Kepala Bidang kecuali untuk Sekretariat dijabat oleh salah satu Kepala Sub Bagian karena Sekretaris SKPD telah menjabat sebagai PPK-SKPD dan staf yang ada di Sub Bagian Perencanaan dan Keuangan dilakukan penelusuran dimana ternyata terdapat perbedaan persepsi antara pihak auditor dari Inspektorat Provinsi Sulawesi Utara dengan Bidang Perbendaharaan BPK-BMD Provinsi Sulawesi Utara. Perbedaan persepsi terjadi tepat sesuai dengan permasalahan yang dikemukakan dalam Laporan Hasil Pemeriksaan oleh Tim Auditor dari Inspektorat, perbedaannya terdapat pada Persepsi pemakaian/penggunaan kata. Sedikit penjelasan bahwa dalam beberapa Kegiatan yang tertata dalam Dokumen Pelaksanaan Anggaran pada Badan Kepegawaian Daerah provinsi Sulawesi Utara khususnya untuk Tahun Anggaran 2013 terdapat Rincian Belanja Makan Minum, Belanja makan minum sendiri terdiri dari Sub Rincian Belanja Makan Minum Rapat, Makan Minum Kegiatan dan Makan Minum Tamu yang semuanya diatur dengan menggunakan Kode Rekening yang berbeda jadi bisa saja terdapat Rincian Belanja Makan Minum dan semua Sub Rincian Belanja Makan Minum dalam satu kegiatan yang sama. Pertanggungjawabannya dibuat sesuai dengan peruntukkan anggaran dimaksud sesuai dengan Rincian Belanja dan Sub Rincian Belanja selama Kegiatan Belanja yang dilakukan tidak salah peruntukkannya dan tidak melebihi dari Pagu Angaran yang tersedia dalam Dokumen Pelaksanaan Anggaran Satuan kerja Perangkat Daerah (DPA-SKPD). Perbedaan Persepsi ini kemudian dianggap sebagai sesuatu hal yang sangat mengganggu karena bukan saja SKPD menjadi ragu dan takut untuk mempertanggungjawabkan kegiatan khususnya dalam Kegiatan Belanja Makan Minum dan Sub Rincian Belanja Makan Minum Rapat, Makan Minum Kegiatan dan Makan Minum Tamu tetapi dalam kenyataannya perbedaan ini menimbulkan kerugian bagi SKPD yang melaksanakan kegiatan karena dianggap tidak mampu mempertanggungjawabkan penggunaan anggaran untuk pelaksanaan kegiatan, tidak mampu menyertakan bukti pengeluaran yang sah dan banyak dokumen yang tidak lengkap sehingga tidak hanya mendapatkan teguran atau peringatan secara tertulis tetapi lebih jauh dituntut untuk mengembalikan kerugian atas belanja dimaksud yang diangap tidak dapat dipertanggungjawabkan. Adanya kesalahan ini pasti berakibat pada Opini yang akan dikeluarkan oleh BPK RI sebagai auditor eksternal pemerintah.

Perencanaan dimulai sejak Badan Kepegawaian Daerah Provinsi Sulawesi Utara (Selanjutnya disingkat BKD Prov. Sulut) menyusun Rencana Kerja Anggaran Satuan Kerja Perangkat Daerah (RKASKPD) yang kemudian dalam mekanisme penyusunan Anggaran Pendapatan dan Belanja Daerah (APBD) sesuai dengan jadwal akan dibahas dalam rapat pembahasan oleh Tim Anggaran Pemerintah Daerah dan Tim Evaluasi RKA-SKPD dimana untuk anggota dari masing-masing Tim ditetapkan dengan Surat Keputusan Gubernur Sulawesi Utara. Dengan mengacu kepada Peraturan Menteri Dalam Negeri (Permendagri) yang setiap tahunnya diterbitkan sebagai pedoman untuk penyusunan anggaran tahun berikutnya, dan kemudian dimantapkan dengan serangkaian aturan pendukung yang menjabarkan secara lebih detail meknisme penyusunan APBD antara lain : Peraturan Menteri Keuangan mengenai Standar Biaya Masukan yang berlaku secara nasional dan digunakan baik di semua pemda maupun jajaran kementerian dan lembaga yang akan menjadi patokan atau standar bagi SKPD dalam menyusun anggaran, Standar Biaya Masukan yaitu penjabaran yang lebih detail dari PMK yang merupakan besaran 
satuan belanja yang berfungsi sebagai estimasi dan batas tertinggi dari volume dan satuan belanja, kemudian ada dokumen pendukung berupa Analisis Standar Belanja (ASB) yang merupakan standar yang digunakan untuk mengukur apakah masukan anggaran untuk pelaksanaan suatu kegiatan masih dalam wilayah yang rasional atau telah melampaui batas wilayah rasional dengan formulasi khusus yang dirancang untuk memberikan ruang kepada SKPD menyusun anggaran untuk pelaksanaan kegiatan dalam range normal sesuai dengan masukan dan keluaran kegiatan yang dilaksanakan. Ada juga dokumen Standar Satuan Harga yang gsetiap tahunnya diterbitkan oleh Bidang Barang Milik Daerah yang berfungsi sebagai dasar/standar dalam penetapan harga barang/ yang akan diadakan sehubungan dengan pelaksanaan kegiatan dan anggaran untuk menunjang operasional teknis dari SKPD, hal ini dimaksudkan agar terdapat keseragaman dalam penetapan harga yang digunakan antar SKPD dimana harga-harga yang ditetapkan dalam Standar Satuan Harga tersebut telah merupakan hasil dari survey ke sejumlah provider atau supplier atau penyedia barang dimaksud, sehingga harga-harga tersebut telah dikomparasi untuk mendapatkan harga yang paling rasional diperhitungkan dengan pengenaan pajak dan disesuaikan dengan situasi dan kondisi daerah. Semua dokumen pendukung tersebut ditetapkan melalui Keputusan Gubernur Sulawesi Utara agar menjadi jelas dasar hukum dalam pelaksanaannya.

Dalam Pembahasan sering terjadi beda persepsi antara sesama tim pambahas yang setelah diamati oleh peneliti hal ini ternyata adalah bagian dari perbedaan persepsi, pemahaman, penafsiran atas aturanaturan yang berlaku untuk proses penyusunan APBD. Sebagai contoh : Dalam Standar Biaya Masukan diatur tentang mekanisme pengadaan pakaian seragam (PSH, PSL, PSH, PSR, Batik Khusus/Bentenan, Pakaian Olahraga, Pakaian Lapangan, Pakaian Laboratorium, dan lain-lain). Dalam SBM disebutkan bahwa dalam satu tahun anggaran SKPD hanya di mungkinkan untuk menganggaran satu jenis pakaian dinas untuk satu orang pegawai. Dalam Pembahasan dualisme persepsi yang muncul adalah bahwa, SKPD harus memilih satu jenis pakaian untuk diadakan dalam satu tahun anggaran berlaku untuk semua pegawai baik dalam jenjang struktural maupun staf serta Unit Pelaksana Teknis Dinas (UPTD) Teknis sekalipun, sementara persepsi lain yang muncul adalah dimungkinkan kepada SKPD yang bersangkutan untuk mengadakan lebih dari satu jenis pakaian dinas selama satu orang pegawai hanya menerima satu jenis pakaian dinas dalam satu kali pengadaan dalam satu tahun anggaran, jadi pejabat struktural dapat berbeda dengan staf maupun petugas teknis lapangan. Contoh lain dalam hal perbedaan persepsi adalah bahwa ada beberapa tim pembahas yang mensyaratkan penganggaran untuk makan minum dalam RKA SKPD harus benar-benar mengikuti standar harga yang ditetapkan dalam SBM sementara yang lain tidak terlalu kaku dalam hal penerapan SBM dalam penganggaran, menurutnya bebarapa bagian dalam SBM yang berfungsi sebagai estimasi atau batas tertinggi dapat disesuaikan dengan kemampuan belanja atau pagu anggaran SKPD yang bersangkutan selama tidak menyimpang terlalu jauh dari batas estimasi yang ditetapkan dalam SBM.

Salah satu permasalahan lain yang muncul adalah tentang perbedaan penafsiran antara SKPD pengguna produk hukum yang diterbitkan oleh Bidang Anggaran BPK-BMD Prov. Sulut yaitu SBM dimana dalam SBM untuk penetapan standar honorarium bagi Satuan Pengelola Keuangan SKPD tidak disebutkan dasar dari Penetapan angka honorariumnya apakah dari Jumlah Total Pagu Anggaran Belanja Langsung dan Belanja Tidak Langsung atau hanya berdasarkan pagu yang tersedia untuk Belanja Langsung, serta nilai paket pengadaan untuk pejabat dan panitia pengadaan sehingga banyak SKPD yang salah menganggarkan untuk jumlah honorarium dan hal ini menjadi temuan dari Pemeriksaan Inspektorat dan BPK-RI atas pengelolaan keuangan daerah Provinsi Sulawesi Utara yang tidak sesuai dengan aturan dan SKPD harus menanggung konsekwensi dari hal tersebut dengan menyetorkan selisih kelebihan pembayaran honorarium tersebut ke Kas Negara sebagai bentuk Tuntutan Ganti Rugi (TGR) atas kerugian Negara. Hal ini tentu saja sangat merugikan pihak SKPD yang notabene menjadi korban dari kesalahan penafsiran dan pemahaman atas aturan yang pada beberapa bagiannya terdapat ambiguitas atau kekurang-pastian maksud dan tujuan. Komunikasi juga menjadi hal yang tidak kalah penting karena sebagaimana teori yang dikemukakan sebelumnya bahwa kesalahan persepsi atas suatu hal dapat terjadi akibat kurang maksimalnya proses komunikasi. Dapat dilihat dengan jelas bahwa dalam proses pembahasan RKA SKPD -dimana dokumen ini nantinya menjadi Dokumen Pelaksanaan Anggaran Satuan Kerja Perangkat Daerah (DPA-SKPD) setelah ditetapkan melalui Peraturan Daerah (Perda) tentang APBD dan menjadi dasar bagi SKPD dalam melaksanakan program dan kegiatan terkait tupoksi 
masing-masing dalam urusan pemerintahan daerah- terdapat proses komunikasi yang kurang maksimal dalam kasus untuk menjelaskan keterkaitan antara Input, Output, Outcome dan Komponen Belanja pendukung pelaksanaan kegiatan seringkali pihak SKPD susah untuk menjelaskan kepada pihak Tim Evaluator karena pejabat pelaksana kegiatan teknis yang bersangkutan tidak hadir atau hanya diwakili oleh pejabat lain atau staf yang kurang memahami tupoksi teknis dari pejabat yang bersangkutan. Sehingga apa yang diharapkan oleh kedua belah pihak seringkali menjadi bertentangan padahal pihak SKPD yang terkadang kurang bisa mengkomunikasikan secara detail maksud dan tujuan dari pelaksanaan program dan kegiatan terkait dengan Komponen Belanja dan alokasi anggaran.

\subsection{Interpretasi Hasil Wawancara}

Proses pengamatan atas fenomena dan permasalahan yang diangkat dalam penelitian ini sebenarnya telah lama dilakukan oleh peneliti, dimulai sejak peneliti menjadi Pegawai Negeri Sipil yang ditempatkan pada Sub Bagian Perencanaan dan Keuangan Sekretariat Dinas Kelautan dan Perikanan pada bulan Februari 2009 sampai dengan bulan Maret Tahun 2012, kemudian dilanjutkan pada saat peneliti dipindahtugaskan ke Unit Kerja/SKPD lainnya yaitu di Badan Kepegawaian Daerah Provinsi Sulawesi Utara dan memperoleh Ijin Belajar utnuk melanjutkan ke Jenjang Studi Strata Dua (S2) pada Program Studi Magister Akuntansi Fakultas Ekonomi Universitas Sam Ratulangi pada Tahun 2012. Peneliti semakin tertarik untuk mengangkat permasalahan perbedaan persepsi tentang pertanggung jawaban pelaksanaan kegiatan anggaran belanja langsung pada SKPD setelah beberapa kali menjadi objek pemeriksaan dan terlibat secara langsung dalam proses pengelolaan keuangan daerah dan pertanggung jawaban pengelolaan keuangan daerah sebagai Pembuat Laporan Keuangan pada SKPD dimana peneliti melaksanakan tugas, apalagi pada beberapa kasus pemeriksaan terdapat temuan-temuan yang jumlahnya cukup material yang sebenarnya menurut peneliti itu hanyalah akibat perbedaan persepsi, pemahaman, penafsiran komunikasi yang tidak efisien dan efektif. Adapun alasan kenapa peneliti memilih Belanja Langsung sebagai variable dalam penelitian ini karena Dalam Penganggaran Belanja Langsung merupakan belanja yang dilakukan sebagai dampak langsung karena adanya kegiatan-kegiatan dan program-program yang dilakukan oleh organisasi, dalam hal ini pemerintah.

Jika belanja langsung merupakan biaya yang langsung timbul sebagai akibat dari adanya pelaksanaan suatu program atau kegiatan maka hasil atau output dari anggaran belanja langsung dapat diperbandingkan dengan hasil atau pencapaian program yang dihasilkan. Artinya penggunaan anggaran ini berdampak secara langsung pada output yang dapat terukur, dan pertanggungjawabannya jelas. Beberapa temuan yang menjadi objek pengamatan dari peneliti adalah soal penggunaan nomenklatur belanja "Makan Minum". Dalam DPA SKPD BKD Prov. Sulut terdapat komponen nbelanja makan minum untuk hampir semua kegiatan, baik kegiatan yang dilaksanakan dengan melibatkan peserta dari luar instansi atau dari dalam instansi. Terdapat program Peningkatan Kapasitas Sumber Daya Aparatur dengan Kegiatan antara lain :

1. Bimbingan Teknis Impelemtasi Peraturan Perundang-Undangan;

2. Pelatihan Kantor Sendiri Bagian Kepegawaian (In-House Training);

3. Sosialisasi Peraturan Perundang-Undangan Kepegawaian;

4. Workshop Kepegawaian

Rata-rata waktu pelaksanaan untuk kegiatan tersebut adalah 1 (satu) sampai dengan 3 (tiga) hari dimana orientasi pesertanya adalah dari dalam dan dari luar instansi BKD Prov. Sulut. Dimana untuk masing-masing pelaksanaan kegiatan terdapat komponen belanja makan minum. Komponen belanja makan minum sendiri terbagi atas tiga rekening masing-masing : makan minum rapat, makan minum tamu, dan makan minum kegiatan. Pada saat kegiatan telah selesai dilaksanakan dibuatlah dokumen Surat Keterangan Pertanggungjawaban (disingkat SPJ) sebagai bentuk pertanggungjawaban atas pelaksanaan kegiatan dimaksud. Pada saat dokumen tersebut lengkap maka dokumen tersebut akan diverifikasi oleh staf pembantu PPK yang mempunyai fungsi verifikasi untuk kemudian di sampaikan kepada PPK untuk di teliti lagi sebelum akhirnya oleh bendahara pengeluaran disampaikan ke Bidang Perbendaharaan BPKBMD untuk 
Diteliti lagi kelengkapannya apabila dokumen tersebut dinyatakan lengkap maka akan dibuatkan Surat Perintah Pencairan Dana (SP2D) yang ditandatangani oleh Kepala BPK-BMD Provinsi Sulawesi Utara yang telah didelegasikan kewenangannya kepada Kepala Bidang Perbendaharaan. Setelah SP2D ditandatangani dokumen tersebut kemudian menjadi dasar pembayaran dana yang digunakan untuk pelaksanaan kegiatan. Dokumen yang di sertakan untuk penerbitan SP2D kemudian dikembalikan ke SKPD. Dokumen tersebut kemudian di arsipkan biasanya dalam wadah berupa ordner yang diberi label tergantung pada jenis pencairan yang dilakukan. Pada BKD Prov. Sulut dokumen pertanggungjawaban biasanya di arsipkan di ordner yang diberi label sesuai jenis permintaan pencairan dana kemudian diletakkan di dalam lemari yang sengaja di desain untuk filing berkas/dokumen pertanggungjawaban. Pada saat Inspektorat melakukan pemeriksaan atas pertanggungjawaban pengelolaan keuangan daerah -di SKPD anggaran digunakan untuk pelaksanaan program dan kegiatan sesuai dengan anggaran yang tertata dalam DPA-SKPD - biasanya dokumen yang diminta adalah dokumen pertanggungjawaban pelaksanaan kegiatan yang oleh SKPD dokumen yang diserahkan ke Inspektorat adalah dokumen yang sama yang digunakan untuk permohonan pencairan anggaran ke Bidang Perbendaharaan BPK-BMD. Setelah diperiksa oleh Tim Pemeriksa dari inspektorat, ditemukan bahwa terdapat beberapa kekurangan dalam dokumen pertanggungjawaban kegiatan terkait pelaksanaan program Peningkatan Kapasitas Sumber Daya Aparatur, Kegiatan Workshop dan Sosialisasi Peraturan Perundang-Undangan tentang Kepegawaian. Dalam pemeriksaan ini yang menjadi sorotan adalah rekening belanja makan minum, dimana dalam Pokok-Pokok Hasil Pemeriksaan (P2HP) dikatakan bahwa dalam dokumen pertanggungjawaban BKD terdapat ketidak cukupan bukti yang memadai tentang pertanggungjawaban penggunaan dana untuk belanja makan minum. Hal ini terjadi karena ketidaksamaam persepsi tentang pemahaman penggunaan nomenklatur belanja untuk masing - masing rincian belanja makan minum yang terdiri dari : makan minum rapat, makan minum tamu dan makan minum kegiatan. Pada kenyataannya makan minum kegiatan yang didalamnya termasuk perhitungan makan minum untuk pelaksanaan lembur atas persiapan palaksanaan kegiatan. Pada pelaksanaan nya makan minum lembur di masukkan ke dalam kategori makan minum kegiatan dengan maksud bahwa makan minum lembur adalah makan minum yang diperuntukkan untuk menunjang kegiatan dalam rangka persiapan atau evaluasi atas pelaksanaan kegiatan. Sehingga makan minum lembur pegawai yang terlibat dalam pelaksanaan kegiatan (biasanya ditetapkan dengan SK kepala SKPD/Sekretaris Daerah/Gubernur) dipertanggungjawabkan dalam bentuk makan minum kegiatan. Karena pada dasarnya bentuk pertanggungjawaban untuk masing-masing rincian belanja berbeda dalam hal kelengkapan dokumen dan komponen didalamnya. Tim Pemeriksa pada waktu itu tidak menerima konsep dimaksud sehingga mereka mengangkat masalah ini menjadi temuan dan dimuat dalam Pokok-Pokok Hasil Pemeriksaan (P2HP) dengan "dakwaan" pelanggaran Pasal 132 ayat 1 Peraturan Menteri Dalam Negeri Nomor 13 Tahun 2006 tentang Pedoman Pengelolaan Keuangan Daerah yang menyatakan bahwa : "Setiap pengeluaran belanja atas beban APBD harus didukung dengan bukti yang lengkap dan sah", dengan indikasi kerugian negara yang lumayan besar.

\subsection{Pembahasan}

Dalam Pelaksanaan Program dan Kegiatan Badan Kepegawaian Daerah sebagaimana yang tertata dalam Dokumen Pelaksanaan Anggaran SKPD tetap mengacu pada Peraturan Menteri Dalam Negeri Nomor 13 Tahun 2006 Tentang Pedoman Pengelolaan Keuangan Daerah, terutama pada pasal-pasal yang mengatur tentang mekanisme pelaksanaan belanja langsung, dan mekanisme pertanggungjawaban pelaksanaan kegiatan Belanja Langsung antara lain Pasal 52, Pasal 121, Pasal 122, Pasal 132 dan Pasal 220, dan aturan - aturan pendukung lainnya yang mengatur secara lebih terperinci hal-hal yang perlu diperhatikan dalam pelaksanaan APBD, seperti Peraturan Gubernur Sulawesi Utara tentang Kebijakan Pelaksanaan APBD, Peraturan Gubernur Sulawesi Utara tentang Kebijakan Akuntansi dan Peraturan Lainnya selam peraturan tersebut tidak bertentangan dengan Peraturan yang lebih tinggi dan disesuaikan dengan kebutuhan pelaksanaan kegiatan, seperti aturan-aturan yang dipakai untuk pengadaan barang/jasa pemerintah, disiplin Pegawai Negeri Sipil dan lain-lain.

Dalam fungsi pengawasan, Inspektorat Provinsi Sulawesi Utara juga menggunakan aturan-aturan yang sama dalam menilai akuntabilitas pelaksanaan kegiatan SKPD dalam hal ini Badan Kepegawaian Daerah Provinsi Sulawesi Utara. Aturan yang digunakan juga disesuaikan dengan teknis atau kebutuhan dan tujuan dari pelaksanaan program pemeriksaan. Misalnya untuk audit kinerja dan disiplin PNS maka 
Aturan yang digunakan adalah Peraturan Pemerintah Nomor 53 Tahun 2010 tentang Disilpin PNS, atau ketika pemeriksaan ditujukan secara spesifik mengenai mekanisme pengadaan barang dan jasa pemerintah maka aturan yang dipakai sebagai acuan adalah Peraturan Presiden Republik Indonesia Nomor 54 Tahun 2010 Tentang Pengadaan Barang/Jasa Pemerintah sebagaimana telah diunah beberapa kali terakhir dengan Peraturan Presiden Republik Indonesia Nomor 172 Tahun 2014 tentang Perubahan Ketiga atas Peraturan Presiden Republik Indonesia Nomor 54 Tahun 2010 Tentang Pengadaan Barang/Jasa Pemerintah, maupun dalam pemeriksaan terkait penggunaan anggaran auditor bisa menggunakan aturan yang dipakai oleh SKPD yang bersangkutan sebagai dasar, misalnya Perda tentang APBD, Peraturan Gubernur Sulawesi Utara tentang Penjabaran APBD, bahkan dokumen-dokumen perencanaan seperti Rencana Strategis dan Rencana Kerja SKPD juga dapat digunakan sebagai acuan dalam pemeriksaan.

Yang menjadi inti dari permasalahan adalah adanya perbedaan pemahaman tentang pertanggungjawaban pelaksanaan anggaran untuk belanja langsung yang berusaha diteliti oleh peneliti. Peneliti mencoba menganalogikan perbedaan tersebut dengan menggunakan sebuah barang yang jika dilihat dalam tiga posisi dan sudut pandang maka akan menimbulkan tiga interpretasi atau penafisran yang berbeda. Ada beberapa hal yang dapat ditemukan oleh peneliti walaupun harus diakui bahwa penelitian ini penuh dengan keterbatasan dimana peneliti dalam melaksanakan tugas sebagai PNS di Lingkungan Pemerintah Provinsi Sulawesi Utara telah tiga kali dimutasikan pada tiga jenis instansi yang berbeda secara teknis pelaksanaan kegiatan, sehingga waktu untuk pengamatan tidak cukup lama, tetapi ada kecenderungan yang sama yang diperoleh oleh peneliti selama melakukan penelitian yaitu adanya kekhawatiran dari auditee pada saat auditor menginformasikan untuk melakukan pemeriksaan. Ini seharusnya secara psikologi bertentangan dengan fungsi pengawasan internal oleh inspektorat, dimana inspektorat seharusnya menjadi mitra SKPD dalam meluruskan pandangan-pandangan yang salah tentang pertanggungjawaban pelaksanaan kegiatan/anggaran, sehingga SKPD yang menjadi auditee tidak perlu sungkan untuk bertanya atau dengan senang hati diperiksa oleh inspektorat dalam upaya bersama untuk menciptakan akuntabilitas pengelolaan keuangan daerah di Provinsi Sulawesi Utara. Kedua adalah kecenderungan adanya temuan oleh BPK - RI sekalipun telah diperiksa oleh Inspektorat. Kecenderungan lain adalah kurangnya fungsi pembinaan oleh inspektorat dalam hal ini meluruskan paradigma yang salah oleh SKPD dalam pelaksanaan APBD karena dalam beberapa proses pemeriksaan yang sempat diamati oleh peneliti kesalahan-kesalahan yang dilakukan oleh SKPD biasanya ada yang dikonfimasi ada juga yang langsung dimasukkan dalam Pokok-Pokok Hasil Pemeriksaan (P2HP) tanpa dikonfirmasi dan tanpa dilakukan pembinaan. Sehingga SKPD berusaha memberikan tanggapan yang jika dianggap ada indikasi kerugian Negara langsung dimasukkan dalam Laporan Hasil Pemeriksaan untuk ditindak lanjuti. Sangat jarang ditemui auditor yang berusaha menjelaskan mekanisme pengelolaan keuangan yang benar secara aturan kepada pelaksana kegiatan. Kesan yang timbul adalah kesan menghakimi bukan memberikan pembinaan. Dalam beberapa kasus yang telah diungkapkan oleh peneliti dalam bagian sebelumnya juga menimbulkan pertanyaan tentang konsistensi aturan yang dipakai dalam pemeriksaan maupun pemahaman aturan tersebut secara komprehensif. Masalah komunikasi juga menjadi salah satu masalah yang muncul dalam kasus ini. Hal ini yang berusaha dijembatani oleh peneliti untuk menemukan solusi atas permasalahan yang diangkat dalam penelitian ini. Peneliti mencoba untuk mengungkap kecenderungan yang terjadi dilapangan, meneliti gejala dengan tidak mengurangi independensi dalam posisi sebagai staf di SKPD yang menjadi fokus studi kasus dalam penelitian ini, dalam upaya memimalisir temuan-temuan yang seharusnya dapat dicegah jika terdapat satu kesepahaman antara Badan Kepegawaian Daerah selaku auditee dan Inspektorat Provinsi Sulawesi Utara selaku Instansi dengan fungsi pengawasan, dalam upaya menciptakan iklim pengelolaan keuangan yang kondusif dalam upaya memberikan kontribusi yang nyata bagi Provinsi Sulawesi Utara.

\section{KESIMPULAN DAN SARAN}

\subsection{Kesimpulan}

Berdasarkan hasil wawancara dan interpretasi atas hasil wawancara maka peneliti mengambil kesimpulan bahwa terdapat beberapa masalah yang mengakibatkan terjadinya perbedaan persepsi antara BKD Provinsi Sulawesi Utara dengan Inspektorat Provinsi Sulawesi Utara antara lain : 
1. Kurangnya pengetahuan dari BKD Provinsi Sulawesi Utara mengenai aturan-aturan di bidang pengelolaan keuangan daerah, yang mengakibatkan mereka susah untuk memberikan argumentasi pada saat terjadi pemeriksaan oleh Auditor baik internal maupun eksternal sehingga dalam setiap pemeriksaan selalu ada temuan-temuan yang seharusnya jika SKPD benar-benar mengerti aturan tentang pengelolaan keuangan daerah maka pelaksanaan kegiatan yang menggunakan uang Negara lewat APBD dapat dipertanggungjawabkan secara moril dan materil, sehingga sekalipun P2HP telah diterbitkan pihak SKPD dapat memberikan sanggahan dengan dasar aturan yang dipakai (Jika diperlukan).

2. SKPD kurang memanfaatkan fungsi Inspektorat sebagai pengawas intern yang seharusnya SKPD dapat melakukan konsultasi - konsultasi terkait mekanisme dan prosedur pertanggungjawaban anggaran yang benar sehingga terjalin Komunikasi yang baik antara Inspektorat dan SKPD hal ini dapat meminimalisasi rasa segan dan takut untuk bertanya dan menjawab dan diharapkan jumlah temuan terkait pengelolaan keuangan daerah dapat berkurang.

3. Kurang Konsistennya Program Audit dari Inspektorat sehingga menimbulkan jenis temuan yang berbeda pada kasus yang sama, seharusnya Tim Pemeriksa secara konsisten menerapkan satu jenis standar pemeriksaan yang digunakan untuk menghindari dualisme pemahaman antar sesame tim pemeriksa.

4. Masih kurangnya kompetensi Auditor dan Fungsional P2UPD sehingga dibutuhkan peningkatan kapasitas dan kompetensi Fungsional Auditor dan P2UPD yang diharapkan akan menghasilkan Tenaga-tenaga fungsional yang benar-benar berkompeten, dan menguasai bidangnya. Memiliki tanggung jawab moral atas kemajuan pengelolaan keuangan daerah khususnya di Provinsi Sulawesi Utara dan memiliki Integritas yang baik sehingga independensi dalam pemeriksaan benar-benar terjaga atau dengan kata lain tidak mudah "terkontaminasi" oleh atmosfir pemeriksaan yang kurang kondusif sekalipun.

\subsection{Saran}

Berdasarkan Hasil Pembahasan dan Kesimpulan yang dapat diambil oleh peneliti maka peneliti mencoba memberikan saran dan masukan untuk para pihak yang menjadi objek penelitian dari penelitian antara lain BKD Provinsi Sulawesi Utara dan Inspektorat Provinsi Sulawesi Utara. Dengan harapan agar saran-saran yang diberikan oleh peneliti dapat diaplikasikan dan memberikan sumbangan dalam sinergitas membangun Sulawesi Utara tercinta dalam mewujudkan Pengelolaan Keuangan yang bersih, transparan dan akuntabel demi meraih penghargaan opini tertinggi noleh BPK-RI dalam pengelolaan keuangan daerah.

1. Untuk BKD Provinsi Sulawesi Utara :

a. Lebih teliti dalam memahami aturan-aturan terkait pengelolaan keuangan daerah, sebaiknya setiap kebijakan pemerintah yang ditetapkan dengan peraturan baik Peraturan Daerah, Peraturan Gubernur, Surat Edaran dan lain-lain terkait tata cara, prosedur, mekanisme pengelolaan dan pertanggungjawaban keuangan daerah agar dipelajari lebih dalam setiap poin, setiap bab, karena jika tidak dipelajari secara komprehensif mungkin kita tidak akan bias menangkap tujuan dari aturan tersebut, sehingga sebisa mungkin aturan tidak dipelajari secara parsial saja.

b. Dalam melakukan pertanggungjawaban pelaksanaan kegiatan agar meningkatkan intensitas koordinasi dan konsultasi dengan pihak-pihak terkait, antara lain dengan Bidang Perbendaharaan BPK-BMD Provinsi Sulawesi Utara untuk kelengkapan dokumen pencairan anggaran dan Inspektorat provinsi Sulawesi Utara terkait mekanisme dan kelengkapan dokumen pertanggungjawaban secara aturan yang berlaku untuk pemeriksaan.

c. Agar memaksimalkan fungsi terkait kajian produk hukum sehingga tidak terjadi salah pemahaman, penafsiran dan interpretasi akan setiap peraturan yang digunakan sebagai dasar pelaksanaan tupoksi baik dibidang kepegawaian maupun pengelolaan keuangan daerah.

2. Untuk Inspektorat Provinsi Sulawesi Utara :

a. Dalam hal pengawasan pengelolaan keuangan daerah, Inspektorat Provinsi Sulawesi Utara dapat melakukan sosialisasi mengenai aturan-aturan terkait pemeriksaan atas pelaksanana kegiatan/anggaran oleh SKPD. Terkait komponen-komponen yang harus dilengkapi guna 
memenuhi tuntutan yang disyaratkan oleh Undang-undang/Peraturan yang terkait mekanisme pertanggungjawaban pengelolaan keuangan daerah.

b. Sebagaimana yang terungkap dari hasil wawancara dengan salah satu petugas fungsional P2UPD dimana pada suatu kondisi tertentu Auditor terkadang susah mengkomunikasikan alasan, dasar atau tujuan dari temuan yang sekalipun maksudnya baik yaitu untuk membantu SKPD dalam hal meluruskan pandangan-pandangan yang salah mengenai pertanggungjawaban pengelolaa keuangan daerah terutama untuk meminimalisir temuan-temuan terkait kesalahan dalam administrasi, tetap saja terkadang SKPD salah menginterpretasikan temuan tersebut akibat perbedaan interpretasi mengenai mekanisme pertanggungjawaban pengelolaan keuangan daerah. Maka diperlukan suatu wadah dimana pihak-pihak yang terkait dapat mengkomunikasikan segala sesuatu hal yang sering menjadi permasalahan dalam pengelolaan keuangan daerah. Komunikasi sangat diperlukan dan dalam situasi ini tidak perlu ada batasan yang membatasi masing-masing pihak dalam berinteraksi, sehingga diharapkan dapat dihasilkan suatu kesepakatan tentang tata cara dan mekanisme pelaksanaan dan pertanggungjawaban pengelolaan keuangan daerah. Kesepakatan ini juga sekaligus memberikan jaminan bagi masing-masing fungsi terkait dalam proses pelaksanaan, pengendalian dan pertanggungjawaban pengelolaan keuangan daerah untuk menjalankan tupoksi masing-masing tanpa ada intimidasi dan rasa ketidakpercayaan.

c. Peneliti menyarankan agar dilakukan sosialisasi dan Focus Disscusion Group (FGD) dengan tujuan tercapainya satu persepsi tentang pengelolaan keuangan daerah yang lebih transparan dan akuntabel sehingga semua pihak yang terlibat sebagai pelaku dalam pengelolaan keuangan daerah dapat saling bersinergi dan secara aktif memberikan kontribusi yang nyata bagi kemajuan pengelolaan keuangan daerah di Provinsi Sulawesi Utara, sebab hal ini secara langsung berpengaruh pada Pemberian Opini oleh BPK-RI dalam hal pemeriksaan terkait transparansi dan akuntabilitas pengelolaan keuangan daerah.

d. Perlu ditingkatkan intensitas Pelatihan atau Bimbingan teknis bagi para auditor dan fungsional P2UPD dalam hal peningkatan kapasitas sumber daya aparatur. Hal ini bertujuan agar semua auditor dan fungsional P2UPD benar-benar memiliki kompetensi yang memadai untuk mencapai pengelolaan keuangan daerah yang lebih baik. Bukan cum adalam aspek peningkatan keterampilan dan pengetahuan serta pemahaman tentang aturan yang berlaku tetapi juga diharapkan para auditor dan fungsional P2UPD memiliki juga keterampilan dalam berkomunikasi yang dapat meminimalisir perbedaan interpretasi dan persepsi mengenai temuan hasil pemeriksaan. Kalau komunikasi lancar auditee tidak akan salah menginterpretasikan maksud auditor dalam pemeriksaan sehingga esensi dari pemeriksaan itu sendiri akan tercapai.

\section{DAFTAR PUSTAKA}

Abdul Halim, 2008. Auditing (dasar-dasar Audit Laporan Keuangan). UUP STIM

Abdul Rahman Saleh, Muhbib Abdul Wahab, 2004. Psikologi Suatu Pengantar Dalam Perspektif. Jakarta : Kencana.

Abu Ahmad, 2003, Psikologi Belajar. Jakarta : Rineka Cipta

Agus Mulyanto, 2009, Sistem Informasi Konsep dan Aplikasi. Yogyakarta : Pustaka Pelajar.

Asmadewa, I, 2006. Faktor-faktor Yang Mempengaruhi Keefektifan Implementasi Anggaran Berbasis Kinerja (Survey pada Pemerintah Pusat). Thesis : UGM.

Baihaqi, dkk, 2005, Psikiatri : Konsep Dasar dan Gangguan-gangguan. Bandung : Refika Aditama.

Bastian Indra, 2007. Sistem Akuntansi Sektor Publik. Jakarta : Salemba Empat

Dedi Nordiawan, dkk, 2007. Akuntansi Pemerintahan. Jakarta : Salemba Empat.

Diah Ananta Setyorini, 2010. Analisis Audit Expectation Gap pada pemerintah daerah (Studi Empiris di Kabupaten Sragen).

Effendy, Onong Uchjana, 2003. Ilmu Komunikasi Teori dan Praktek - Cetakan kesembilan belas. Bandung : PT. Remaja Rosdakarya.

Indrastanti, Retno Sri dan Wahyono, 2009. Persepsi Auditor Publik dan Auditor Intern Terhadap

Struktur Pengendalian Intern . Jurnal Daya Saing Volume 10 Nomor 1. Maret 2009.

Jalaludin Rahmat, 2003. Psikologi Komunikasi. Bandung : PT. Remaja Rosdakarya. 
John M. Ivancevich, dkk, 2006, Perilaku dan Manajemen Organisasi. Bandung : PT. Remaja Rosdakarya.

Mardiasmo, 2009. Akuntansi Sektor Publik. Yogyakarta : ANDI

Mulyana Deddy, Ph. D., M.A, 2005. Ilmu Komunikasi Suatu Pengantar. Bandung PT. Remaja Rosdakarya.

Mulyana Deddy, dan Solatun, 2008. Metode Penelitian Komunikasi : Contoh-Contoh Penelitian Kualitatif dengan Pendekatan Praktis. Bandung : Pt. Remaja Rosdakarya.

Notoatmodjo, S, 2007. Promosi Kesehatan dan Ilmu Perilaku. Jakarta : Rineka Cipta

Peraturan Pemerintah Nomor 24 Tahun 2005 tentang Standar Akuntansi Pemerintahan.

Peraturan Pemerintah Nomor 58 Tahun 2005 tentang Pengelolaan Keuangan Daerah.

Peraturan Menteri Dalam Negeri Republik Indonesia Nomor 13 Tahun 2006 tentang Pedoman Pengelolaan Keuangan Daerah. Kementerian Dalam Negeri.

Purba Amir, dkk, 2006. Pengantar Ilmu Komunikasi. Bandung : PT. Remaja Rosdakarya.

Poerwandari, E.K, 2007. Pendekatan Kualitatif untuk Penelitian Perilaku Manusia. Jakarta : LPSP3 UI

Rakhmat, Jalaludin, 2005. Metode Penelitian Komunikasi. Bandung : PT. Remaja Rosdakarya.

Stephen P. Robbins, Timothy A. Judge, 2009. Perilaku Organisasi Edisi 12. Jakarta : Salemba Empat.

Undang-Undang Nomor 33 Tahun 2004 tentang Perimbangan Keuangan Pemerintah Pusat dan Daerah, Kementerian Dalam Negeri. 